\title{
Hegel and Kant on rational willing: The relevance of method*
}

\section{Sebastian Stein}

\begin{abstract}
Hegel's account of rational willing has recently been misrepresented by both critics and supporters who argue that the content of willing is externally received from history, social context, practices of recognition, etc. This contradicts the conceptual structure of Hegel's notion of rational action as free individuality, according to which the difference between the willing subject and the content of willing is an internal relation of identity. Since this 'difference within identity' can only be grasped by speculative thinking and not through understanding and reflection, the interpreters can be charged with employing the wrong method. Although reliance on the speculative method opens Hegel to the charge of unintelligibility, it helps explain the frequent misrepresentations of his account of freedom and why methodologically uninformed comparisons between Hegel and other thinkers run the risk of being counterproductive.
\end{abstract}

The notion of freedom is central to the project of German Idealism as a whole. ${ }^{1}$ And yet, each of the movement's main representatives has a radically different understanding of this term. While Kant, Fichte, Schelling and Hegel accept a minimal definition of freedom as 'self-determination', they differ in their conception of the relationship between the determining self and the determination it determines itself to and Hegel claims to be the only post-Kantian philosopher successfully to reconcile Kant's notion of undetermined self-determination with a notion of determinacy without falling victim to the dangers of relativism (Hegel 2008: 46, 47), infinite regress (Hegel 2008: 70) or a historization of freedom (Hegel 2008: 21ff).

\footnotetext{
* In alphabetical order, I would like to express my gratitude to Prof. Dr. Karin de Boer, Dr. Michela Bordignon, Dr. Thom Brooks, Dr. Katerina Deligiorgi, Prof. Dr. Markus Gabriel, Susanne HerrmannSinai, Dr. Lisa Herzog, Michael Inwood, Prof. Dr. Stephen Houlgate, Prof. Dr. Anton Koch, Dr. Christian Martin, Dr. David Merrill, Prof. Dr. Adrian Moore, Dr. Sebastian Ostritsch, Prof. Dr. Robert Pippin, Felix Stein, Prof. Dr. Robert Stern, Prof. Dr. Klaus Vieweg, Dr. Lee Watkins and Dr. Lucia Ziglioli for helping me develop the ideas presented in this paper.
} 


\section{Hegel and Kant on rational willing: The relevance of method}

In this paper, I examine this claim by discussing the methodological background of Hegel's criticism of Kant and apply the results to some recent interpretations of Hegel's notion of rational action.

In the Groundwork of the Metaphysics of Morals Kant analyses free willing in terms of the ends pursued by rational subjects (Kant 1998: 8). ${ }^{2}$ Since not all ends are compatible with freedom, the question arises how to recognise those that are. Kant's answer is clear: Any end that is given to the subject externally is incompatible with its freedom (Kant 1998: 11). If the subject did adopt such an end, it would depend on something other than itself. To avoid such dependence, the rational subject must adopt its own ends - it must be self-determining. ${ }^{3}$ The test of successful self-determination and so of freedom is the categorical imperative. ${ }^{4}$

Hegel denies the possibility of meaningful self-determination in this sense and mounts one of the earliest criticisms of the Kantian position in the Pbilosophy of Right. Here, Hegel accuses Kant of "divorcing the "particular" from the "universal" aspects of the will' (Patten 2002: 84) and of leaving the thinker without guidance in the search for rational ends and so without content for her moral duties. ${ }^{5}$ On Hegel's reading, no determined end qualifies as rational or as compatible with the subject's self-determination. The categorical imperative fails to identify any end and consequently, Kant's notion of freedom is without any content, i.e., formalistic. (Hegel 2008: 131)

In her recent book The Scope of Autonomy, Katerina Deligiorgi defends Kant's account of freedom against such criticisms and praises Kant for combining a concern with the freedom of the subject with the notion that morally worthy and thus freedom-compatible ends are valid for all rational beings. ${ }^{6}$ She also criticises Hegel for reducing moral and thus free willing to a question of social convention: '[W] hat is 'real' [about rational willing], for Hegel, turns out to be what is social; that is, the notions and rules that are sustained at any one time by specific social practices'. (Deligiorgi 2012: 185) While Hegel's agent wants to consider her actions as her own, this is only achieved once the actions have been attributed and evaluated according to whatever rules are current in a given society. (Ibid: 189) This equates to 'socializing the agent into a set of rules rather than something we can call "freedom" (ibid.) since finally, "Hegel's thick intersubjective model results in the absorption of action-ascription to evaluation according to rules that are nothing over and above what is socially current at any one time; it is this that I see as the absorption of morality to social etiquette'. (Ibid: 190) Since Hegel's account of rational action fatally relies on social context, it loses the very kind of independence of the moral will that Kant had already successfully conceptualised. (Ibid: 191) $)^{7}$ Deligiorgi is not alone in recently discussing Hegel's critique of Kant (Sedgwick 2012) or in rejecting it (see e.g., Singer 1961, Wildt 1982, Wood 1990) and her criticism articulates the popular 


\section{Sebastian Stein}

position that the content of willing is something externally given to the willing subject.

In what follows, I examine first Hegel's criticism of Kant's conception of freedom. I argue that while Hegel initially follows Kant in analysing rational willing in terms of the ends pursued by a rational subject, he also maintains that there are rational ends that are fundamentally identical with the subject. When the undetermined subject determines itself to pursue these (truly rational) ends, it determines itself to itself and so remains free in its willing. Hegel calls this concept 'individuality' (Einzelheit) and assigns to it the logical structure of a 'difference within an identity' that enables him to claim that rational willing is 'universal' (Hegel 2008: 43), 'truly infinite' (Hegel 2008: 42) and 'unconditioned' (Hegel 2008: 43). I examine the structure and justification of Hegel's conception of freedom as individuality in section two. Although Hegel's own account of rational action as individuality is best appreciated as a response to a fundamental logical problem that resides at the heart of Kant's framework, it also relies on the speculative method of thinking, which substantially differs from Kant's method of understanding and reflection. I set out the differences between these methods in section three before I conclude that many of Hegel's recent interpreters misrepresent his speculative notion of individuality because they describe it in terms of understanding and reflection. Hegel's reliance on the speculative method, preserves a commitment to the difference between subject and end by placing it within an identity.

\section{Hegel's critique of Kant's notion of rational action}

In the remark to the Philosophy of Right's \$135, Hegel praises Kant's moral philosophy for putting autonomy and thus self-determination at the centre of the notion of rational action. ${ }^{8}$ On Hegel's reading, Kant describes rational action as the result of a subject's unconditioned and therefore self-determined choice. When Kant's subject acts rationally (e.g., dutifully), it determines itself without influence by factors that undermine its self-determination such as feelings, inclinations, socially accepted modes of behaviour, assumptions, social pressures, etc.

Hegel disagrees with Kant's notion of pure self-determination because he takes it to define all determinacy as logically opposed to the moral subject and its indeterminacy. ${ }^{10}$ Thereby, so Hegel claims, all the aspects of rational willing that have a determinate and subject-external character such as ends, social norms, institutions and practices, etc., are excluded from the notion of rational willing. This entails that Kant's notion of free rational action, i.e., the subject's self-determination, is a determination to an indeterminate self and is therefore empty. ${ }^{11}$ As soon as Kant's undetermined subject determines itself to an end and 


\section{Hegel and Kant on rational willing: The relevance of method}

thus wills something, it becomes dependent on what is 'other' to itself and loses its freedom. Even Kant's criterion for the identification of morally suitable ends, the categorical imperative, cannot provide the subject with guidance since any determined maxim, social institution or pattern of behaviour it is supposed to identify as being compatible with freedom would have to be compatible with the subject's indeterminacy: It would have to be undetermined, which in turn would contradict the very notion of determinacy. ${ }^{12}$

This critique has been answered in a variety of ways: By pointing to the usefulness of different formulations of the categorical imperative in identifying suitable ends (e.g., Hoy 1989: 208ff) or by focusing on Kant's discussion of virtues in the second part of the Metaphysics of Morals (e.g., Hill 1992). Finally, it is possible to challenge the need for a derivation of morally permissible ends from the categorical imperative alone and point to values such as self-perfection ${ }^{13}$ as an alternative source of content or suggest that there is something about the role a concern with human happiness plays in our thinking ${ }^{14}$ that provides content to our moral willing. ${ }^{15}$

Whatever the strengths of each of these approaches, the Hegelian point remains that in light of Kant's demand that practical reason be 'pure' (Kant 1998: 21) and thus independent from external determination by values, feelings, individual desire for happiness and suchlike, the issue of content remains a problem. This is especially pressing once we consider that the crucial formula of the categorical imperative is that of the universal law. Many commentators focus on this formula to extract moral guidance by establishing that there is a contradiction in willing irrational ends. ${ }^{16}$

Alan Patten's views are typical in this respect. Patten sides with Allen Wood (1999: 155-61), Christine Korsgaard (1985), Andreas Wildt (1982: 84-96) and Onora O'Neill (1975) when he argues that ' $t$ t here is a natural interpretation of Kant's test according to which it clearly can generate contradictions and rule some maxims out without at the same time rejecting every maxim. If Kant's test is seen as looking for contradictions between (1) willing the purpose contained in the maxim and (2) willing that the maxim be universalized, then it clearly does have particular content and is not indiscriminate.' (Patten 2002: 85) For purposes of illustration, Patten cites Kant's deposit example where an individual accepts a deposit and considers appropriating it after the depositor's death. According to Patten, Kant thinks that the appropriation would be immoral since 'the agent would, in effect, be willing both that he increase his property (the purpose contained in the maxim) and that the means through which he intends to do this — the institution of deposit-leaving — not be present (the implication of universalizing the maxim); he would be willing both the end and the abolition of the proposed means.' (Patten 2002: 86)

I want to argue that such focus on the agent's behaviour alone is precisely what Hegel takes issue with. In the deposit example, Patten finds the contradiction in the 


\section{Sebastian Stein}

fact that the agent's behaviour simultaneously expresses regard and disregard for the institution of property. While the agent respects the institution of property when he accepts the deposit and honours the depositor's property claim, he would disrespect this very same institution if he were to appropriate the deposit, making his behaviour inconsistent. While this tells us that consistent behaviour with regards to an institution is rational, it does not seem to say much about the rationality of the institution itself. ${ }^{17}$ The point is this: Instead of logically deriving or deducing the moral validity of the institution of property from the notion of the subject's (consistent) behaviour, it seems that Kant must assume the moral worth of the institution independently of the agent's behaviour for the test to work. And yet, the moral validity of the institution should be the result of the categorical imperative's testing process that logically begins with the notion of consistent subjective behaviour. According to Hegel, Kant is unable to justify the moral validity of certain institutions because he cannot logically connect them to the notion of the agent's behaviour.

The same logical gap that prevents the deduction of the worth of the institution from the notion of the agent's consistent behaviour, so Hegel, also entails the possibility that the institution of property is not morally valid. This in turn means that an agent's inconsistent behaviour towards it could not be morally problematic. ${ }^{18}$ While not paying back debt is irrational and thus immoral in a world where property is rational, this is not the case in a world where it is not. Kant is thus right in arguing that the borrowing of money would not be possible in a world without the institution of property but he does not establish that such a world would be irrational.

A possible Kantian rejoinder is that it is not consistency alone that the categorical imperative demands. The logical connection between subjective behaviour and the maxim or institution we are looking for is established through the universalizability requirement. Only when one wills a maxim to be universal, its rationality or irrationality becomes apparent. However, Hegel argues, because Kant equates universality with rationality and rationality with the subject's consistent behaviour, the categorical imperative's universality requirement amounts to the tautological demand that rational behaviour ought to be rational and again fails to logically establish what kind of behaviour is rational.

Since the notion of universally valid behaviour alone contains no further logical content, any determinate institution or maxim can be projected onto the universality-requirement from the outside. ${ }^{19}$ For example, universalising the maxim 'nobody should interact in property-implying ways' does not obviously create a fatal contradiction since it is impossible to imagine a world where everybody behaves in a property-defiant way. ${ }^{20}$ Since any institution can be universalised and respected or disrespected by consistently behaving subjects, no institution or set of institutions can be singled out by the standard of 'consistency 
of behaviour and universality' alone. Kant's consistency and universality criteria do not tell us which institution to universalise and to consistently respect but rather that any institution that is universalised and respected ought to be universalised and respected consistently. This also means that there is nothing in these criteria that can be used to criticise the moral agent's consistent adherence to the institutions of e.g., slavery, oppression, exploitation, etc. Since it is logically possible that an agent consistently wills in a slavery-supporting way or that all possible agents do so (be they slaves or slave-owners), ${ }^{21}$ the consistency requirement of the categorical imperative is not necessarily contradicted by the institution. The "logical contradiction in willing" that Kant mentions as a criterion for identifying valid maxims (Kant 1998: 34) is but an inconsistency within the subject's behaviour. Its failure to logically connect to the content of the institution, i.e., to the idea of which kind of behaviour, entails that it is equally possible for all individuals to participate in any institution. This also applies to the supreme rational ends that Kant describes in the Metaphysics of Morals. ${ }^{22}$ The ends of 'one's own perfection and the happiness of others ${ }^{23}$ cannot be shown to be logically connected to the kind of consistent subjective behaviour that the categorical imperative sets as a standard as it remains logically possible that all agents act consistently in a self-neglecting manner or in ways that defy others' happiness. ${ }^{24}$

According to Hegel, all the weaknesses of Kant's moral framework can thus be traced back to the same fundamental logical difference between consistent subjective behaviour and determinacy. This is true for the logical possibilities of constructing a valid counter-maxim to every maxim that Kant thinks morally valid (which includes universalising immoral maxims), for the impossibility of deriving determinate institutions from consistent behaviour, i.e., the logical incompatibility of subjective behaviour with any end, for the inapplicability of the categorical imperative to any determinate course of action and the possibility of any maxim qualifying as rational, etc. Since Kant fundamentally separates indeterminate subjective behaviour and determinacy, the institutions remain a behaviour-external projection that is brought in from outside. Only a suitable logical link between these notions could fulfil the function of a criterion that differentiates moral institutions from immoral ones and allow for a deduction of one from the other. It is the creation of such a link that Hegel undertakes by designing his own notion of rational willing.

\section{Hegel's account of rational action as individuality}

While several commentators agree that Hegel has at least pointed out some proper difficulties if not fatal flaws of the categorical imperative (e.g., Freyenhagen 2007, Pinkard 1991, Pippin 1991), there is little consensus about the nature of Hegel's 


\section{Sebastian Stein}

own constructive alternative. While systematic ${ }^{25}$ commentators (e.g., Brooks 2007, Yeomans 2012) have begun to consult the Science of Logic in order to uncover the logical structure that informs Hegel's account of rational willing, there is no widespread agreement about which logical categories apply to it most fittingly. In contrast to readings that privilege categories such as reciprocity and actuality (e.g., Patten 1992, Yeomans 2012), I will argue that the most adequate category for framing Hegel's notion of rational willing is what Hegel calls "individuality" or 'the concept' (Hegel 2010: 507ff).

Hegel's description of the logical structure of rational willing in $\$ \int 5,6,7,8$ and 9 of the Philosophy of Right ${ }^{26}$ proceeds in three steps. First, he distinguishes between the two elements of indeterminacy and determinacy and equates the former with Kant's self-determining subject, defining it as 'freedom from determination'. ${ }^{27}$ This element is the negation of determinacy and guarantees that rational willing is not merely natural, determined, conditioned or dependent. The second element is defined as determinateness or determinacy (Bestimmtheit). It is equivalent to Kant's rational end (and thus to a norm, practice or institution), i.e., the determination that is pursued and which provides the content of rational willing. ${ }^{28}$ So far, Hegel seems to be following Kant: Rational action is the pursuit of determined ends by an undetermined subject. However, in his third step, Hegel re-conceptualises the relationship between these elements and claims that while they are different determinations in their own right, rational determinacy is not just different from the subject's pure indeterminacy. Instead, the two are also fundamentally identical. This identity follows from the fact that the two seemingly different terms logically imply each other: While one can only make sense of determinacy if one thinks of it as the negation of indeterminacy, making sense of indeterminacy is only possible by thinking of it as the negation of determinacy. ${ }^{29}$ In other words, rational determinations, norms, practices and institutions are what they are because we logically contrast them with the undetermined subjects that pursue and institute them. Without such subjects, the determinations could not be ends of rational willing. Simultaneously, rationally willing (i.e., essentially indeterminate) subjects cannot act without the existence of rational determinations ${ }^{30}$ - without these, the subjects would not will anything. ${ }^{31}$ Indeterminacy logically implies determinacy as it is indeterminacy and determinacy implies indeterminacy as it is 'not indeterminacy'.

Going one step further, Hegel then argues that the elements' mutual implication entails that they can be described as articulations of the same principle: ${ }^{32}$ Since indeterminacy is the negation of determinacy, which in turn is the negation of indeterminacy, indeterminacy is the negation of the negation of indeterminacy. Similarly, determinacy is the negation of indeterminacy, which in turn is the negation of determinacy so that determinacy is the negation of the negation of determinacy. Independently of where one begins thinking - be it 


\section{Hegel and Kant on rational willing: The relevance of method}

with the indeterminacy of the subject or with the determinacy of the end - one realizes that the respective opposite has the same logical origin as the determination one begins with. This origin is the logical principle that articulates itself as determinacy or as indeterminacy. (Hegel 2008: 31) ${ }^{33}$ For Hegel, the elements' mutual dependency as well as the fact that both can be described as articulations of the same principle entails that the elements' identity encompasses their difference. So when one thinks of the terms as different, one thinks of this difference against the backdrop of their identity. Hegel calls the conceptual identity that contains difference 'individuality' (Einzelheit): ${ }^{34}$

'[Rational willing] is the unity [of indeterminacy and determinacy].

It is [determination] reflected into itself and so brought back to [indeterminacy], i.e., it is individuality.' (Hegel 2008: 31, 32) ${ }^{35}$

In other words, the aspect of rational willing's determinacy, i.e., the rational ends, practices and institutions, are but one dimension (or, in Hegel's words, one logical 'element' (Hegel 2008: 28) or 'moment' (Hegel 2008: 28)) of individuality. The other dimension is the notion of an undetermined, active subject. Since individuality encompasses both of these, the rational ends are individuality in determined form and the activity of the rational agent is individuality in the form of indeterminacy. For Hegel, this implicit identity entails that when rational agents will rationally, i.e., when they choose rational ends, they choose what they are themselves. The rational agent chooses to pursue these ends because they are what the agent is - rational. It is in virtue of this self-referential character of the agents' rational willing that there is no dependency, external conditioning or restriction.

Hegel calls this logical structure "freedom" because it is actively self-referential: When subjects will rationally, they determine themselves to themselves, all content is fundamentally internal to the same category. Hegel's notion of rational willing as individuality is thus designed to articulate two thoughts at the same time: On the one hand, willing subjects and ends are different. When undetermined subjects act, they pursue determined ends. However, when the rational subjects pursue rational ends, they act in a certain, determined way that qualifies as the expression of their own rationality. It is in this successful pursuit of rational determinations that the subjects' identity with the pursued ends is manifest. ${ }^{36}$ While Hegel thus adopts Kant's differentiation between indeterminate rational subjects and determinate rational ends, he also argues that this difference presupposes an identity that accommodates it. According to this identity, rational willing is logically indeterminate and determinate at the same time. ${ }^{37}$

This, so Hegel argues, helps avoid the above-mentioned problems of Kant's categorical imperative-test. Since rational behaviour and rational institutions are fundamentally identical, one is logically connected to the other and so 


\section{Sebastian Stein}

determinate institutions can be logically deduced from the subjects' indeterminacy. Insofar as these elements ultimately are each other, their rational connection is conceptually transparent. While Kant logically begins with their difference and then (tragically) tries to connect them via an identity claim, Hegel's account of individuality begins with the identity claim and explains the elements' difference as a function of it. Since the two elements are already identical within the concept of individuality, their identity does not have to be established against the background of their difference.

From Kant's perspective - and many others - this notion of freedom as individuality will seem rather peculiar. What does it mean that the different logical elements of indeterminate agency and determined end are part of the same conceptual structure? How can they be different and identical ${ }^{38}$ Even if one agrees with Hegel's analysis of Kant's notion of rational willing, it might seem that his alternative comes at an unacceptable conceptual cost. The notion of rational willing as individuality might fail to convince due to the unorthodox logical acrobatics it requires. It might not be thinkable, or at least not be clearly thinkable or thinkable in the way that a philosophical concept or a scientific proposition should be thinkable. These reservations point to a frequently mentioned ${ }^{39}$ but rarely emphasised methodological difference between Kant and Hegel.

\section{Hegel's notion of speculative philosophy}

In the Encyclopedia of Philosophical Science, Hegel distinguishes between three kinds of thinking. He labels them 'understanding', (Hegel 1991: 102) 'dialectical thinking' (Hegel 1991: 102, 103) and 'speculative thinking' (Hegel 1991: 103). ${ }^{40}$ In connection with his critique of Kant, he also mentions the method of reflection that he associates with the concepts of identity, difference and contradiction and which he discusses at some length in the beginning of the Science of Logic's section on the logic of essence. (Hegel 2010: $344 \mathrm{ff}$ ) While understanding and reflection ${ }^{41}$ help to differentiate certain representations, dialectical thinking relates these representations to each other and speculative thinking grasps what positively results from dialectical thinking. For example, in the case of the concept of rational willing, one can understand the different moments of indeterminacy and determinacy by distinguishing them from each other: Indeterminacy is understood as 'not determinacy' and determinacy is understood as 'not indeterminacy', the active agents are not the ends and the ends are not the active agents. Similarly, when one reflects about the relationship between determinacy and indeterminacy, one will come to the conclusion that they are different rather than identical. This difference is then capitalised on by 


\section{Hegel and Kant on rational willing: The relevance of method}

dialectical thinking: The dialectical thinker relates the different determinations that understanding or reflection have identified (Hegel 1991: 102, 103). For example, one might think that 'rational willing is determinate' (it must have content to be real willing). However, if determinacy was all there was to it, who would act? There must also be an undetermined subject for willing to qualify as action - the notion of successful willing must also contain the element of indeterminacy. And yet, thinking of willing in terms of indeterminacy alone will lead one back to the idea that there must be a content to willing and thus a determination et cetera.

To escape from this ultimately negative and potentially unproductive pattern of dialectical thought, so Hegel, one has to resort to speculative thinking. ${ }^{42}$ This method conceptually unites the different elements that the understanding and reflection have identified and dialectical thinking has helped to relate to each other:

'The speculative [method] apprehends the unity of the determinations in their opposition, the affirmative that is contained in their dissolution and in their transition'. (Hegel 1991a: 131) ${ }^{43}$

In the case of rational willing, the notion of individuality is the affirmative content of thought that results from the realization of indeterminacy's and determinacy's mutual logical implication and negation. While it becomes impossible to hold on to either of the terms in isolation, once one thinks about them dialectically, their speculative identity in form of the concept of individuality can be grasped as a positive content of thinking. ${ }^{44}$ This also means that the difference between the elements of indeterminacy and determinateness that understanding and reflection establish and that motivates thinking about them dialectically is not abandoned in the speculative thought of individuality: Freedom as individuality is both, undetermined and determined. But it is more than the mere, logically horizontal 'sum' of the two. It is that, which expresses itself in the difference of these terms. Hegel accordingly warns that it cannot be described as 'determinacy and indeterminacy' i.e., as an equation such as: 'I' (identity) = A (indeterminacy) \& B (determinacy) (see e.g., Hegel 2010: 358 ff). So the kind of identity and difference, or contradiction claims characteristic of reflective thinking, do not apply to the relationship that governs individuality and its elements. Individuality is not just identical or different from determinacy or indeterminacy, nor does it contradict them. Instead, individuality is that which expresses itself in the elements, in their difference and in their relationship. ${ }^{45}$ Insofar as the elements participate in this identity, they are the same and yet, they retain their understanding and reflection based difference insofar as they remain different aspects of the same identity. To think speculatively means to think difference within individuality's identity. ${ }^{46}$ 


\section{Sebastian Stein}

\section{The speculative notion of individuality and recent interpretations}

How do these methodological considerations about Hegel's concept of freedom as individuality relate to the initially mentioned interpretations made by his supporters and critics? It seems that several of these do not take into account Hegel's speculative analysis. In Hegel's Practical Philosophy, Robert Pippin acknowledges that Hegel's notion of willing contains the element of a undetermined, critical subjectivity that aims to identify itself with the ends of its actions (Pippin 2008: 24) so that it can 'stand behind them'. (Pippin 2008: 24, 39) Pippin elegantly describes how this subject wants to experience the rational norms of its action not as something external but as something internal and to see them as 'the subject's own reason'. (Pippin 2008: 43) Yet, when it comes to describing how such an identification is possible, Pippin seems to invoke a historical process rather than a conceptual structure and argues that it is only through learning from the historical failures of given norms that we can come to accept certain norms as our own:

"We still need some alternative way of accounting for how we can be said to make these historically specific attachments, dependencies, social roles, and social ideals our own .... Hegel ... focuses our attention on the experience of normative insufficiency, on a breakdown in a form of life (a situation wherein we cannot make them any longer our own), and thereby, through such a via negativa, tries to provide a general theory of re-constituted positive normative authority out of such breakdowns." (Pippin 2008: 91)

This seems to suggest that the content of rational willing, i.e., the rational norms, forms of life, etc., are something the subjects acquire externally from history. By introducing the idea of a difference between rational subjects and ends, it makes the identity between agent and end a question of historical contingency historically speaking, the learning might as well not take place - rather than describing it as the defining mark of the conceptual structure of individuality. By potentially disconnecting the subjects from the ends, such a reading also entails a problem of logical priority. The notion of a historical learning process seems to presuppose a conceptual grasp of what it is that is learned. If learning means that something rational rather than something irrational is adopted, one has to know what is rational in order to judge that learning has taken place. But what norms, institutions, practices, ways of life, etc., are rational? According to Hegel, only those determinations that can be shown to conceptually participate in the speculative identity with individuality's indeterminacy. The architecture of the 


\section{Hegel and Kant on rational willing: The relevance of method}

Philosophy of Right is based on this notion as it describes the rational determinations of right (e.g., abstract right, morality and ethical life's family, civil society and the state) as parts and expressions of the individuality that is the rational will. From this conceptual perspective, the question which historically manifest norms, institutions, ends, practices, ways of life, etc., are worthy of learning does not arise since rational agent and rational end are always already identical and their difference is the way in which identity is articulated conceptually speaking, the rational agent always already owns the rational end.

Of course, from a conceptually informed, historical perspective, i.e., the perspective of a philosophy of history, this conceptual relationship articulates itself in a historical, social, sometimes global and not always linear learning process about the rationality of certain ends (e.g., it might take a substantial amount of struggle and many detours until rational norms such as property, contract, an ordered economy, etc., are appreciated in a given society). But the recognition of such a process presupposes the notion of rational willing as individuality and its determinations. Insofar as Pippin's reading emphasizes the fundamental difference between subject and end, it can be read to rely on the methods of understanding or reflection rather than on Hegel's speculative thinking.

Another sympathetic interpreter of Hegel's who emphasises the separation of rational agent and end is Christopher Yeomans. In Action and Reflection: Hegel and the logic of agency, he argues that Hegel calls for a 'unity' of agent and end (Yeomans 2012: 26), where the agent's 'internal determination must be compatible with and articulated by external determination.' (Yeomans 2012: 4) Yeomans denies that Hegel's notion of individuality suffices as a description of such a unity and disregards Hegel's identification of individuality with 'the concept' (ibid.). ${ }^{47}$ Instead he describes the elements' unity in terms of the categories necessity (ibid.: 75ff), teleology (ibid.: 235ff) and reciprocity (ibid.: 243ff). While a detailed description of the critique that Hegel offers of these categories in the Science of Logic would go beyond the scope of the present discussion, it should suffice to say that Hegel maintains that all of these categories fail to achieve conceptual stability because they fundamentally differentiate between the elements they ought to speculatively unite. For example, Hegel takes the categories of necessity and reciprocity to assume a reflection-based difference between two entities and then try to connect them by means of an identity claim. (see e.g., Hegel 2010: 477ff and 503ff) They put the terms' difference before their identity. In contrast, the structure of the concept (and thus of individuality) has it the other way around: The elements' speculative identity is what articulates itself in their difference. While the category of teleology avoids the mistake caused by reflection, it still opposes subject (indeterminacy) and object (determinacy) in a way that prevents the desired speculative unity that is only achieved in individuality's final form, the absolute 


\section{Sebastian Stein}

idea. (Hegel 2012: 735ff) Although Yeomans raises the issue of methodology by pointing to the limits of the understanding ('representational thought' (Yeomans 2012: 27)), he rejects the idea that Hegel's notion of individuality successfully situates the difference between agent and end within identity: 'As it stands, [individuality] is far from a positive account of free will, since it is very difficult to understand how we could both integrate and disintegrate [the different aspects of indeterminacy and determinacy] at once' (emphasis added) leading Yeomans to think that the relevant paragraphs of the Philosophy of Right 'simply introduce this as a problem.' (ibid.: 26, 27) Insofar as Yeomans' favoured categories prioritize the difference of the elements of rational willing over their identity, also his interpretation seems to rely on reflection rather than speculation.

A similar observation can be made about the initially discussed Kantian criticism of Hegel made by Deligiorgi. Her claim that Hegel's rational agents receive the content of action from society can be read to rely on the idea that the subject and the end of willing fundamentally differ from each other: While the willing agent is undetermined, the socially determined content is something that the subject receives externally. Since the connection between subject and end is lost here, the ends appear contingent in their relation to the subject and by determining itself to these, the subject is dependent rather than free. While there might be methodological reasons for refusing Hegel's notion of individuality along with the speculative identity it is designed to articulate - e.g., one might not consider the speculative method to be a valid philosophical option - this would have to be explicitly argued for. Otherwise, Hegel could reject such criticisms by referring to their implied commitment to the methods of understanding and reflection as these are the most likely origin of the fundamental logical difference between the elements of rational action. ${ }^{48}$

\section{Sebastian Stein \\ Ruprecht Karls Universität Heidelberg, Germany sebastian.stein@ps.uni-heidelberg.de}

\section{Notes}

\footnotetext{
${ }^{1}$ See e.g., Rosen 2007: 1ff. For an interesting discussion of the importance of this concept on ancient political philosophy and its conceptual relation to German Idealism, see Winfield 2012. ${ }^{2}$ In the Groundwork, Kant treats rational action synonymously with moral action. To act morally is to act (truly) rationally and thus to act freely.

${ }^{3}$ Will is a kind of causality belonging to living beings so far as they are rational. Freedom would then be the property this causality has of being able to work independently of determination by alien causes [...]'. (Kant 1998: 75).
} 


\section{Hegel and Kant on rational willing: The relevance of method}

${ }^{4}$ Whether any of the formulae of the categorical imperative succeed in testing ends is the subject of a long and increasingly complex debate. Some commentators simply reject the idea that the categorical imperative can identify any ends (Freyenhagen 2007, Lottenbach and Tenenbaum1995), others suggest the content of rational willing follows from certain facts about our self-interest in happiness, from certain universal values (e.g., Larmore 2008: 84) or from a process of deliberation (O’Neill 1975, Korsgaard 1985, Rawls 1980 and 1989, Herman 1993). 5 '[A]ll that is left for duty itself [...] is abstract universality, whose determination is identity without content or the abstractly positive, i.e. the indeterminate' (Hegel 2008: 130).

${ }^{6}$ Deligiorgi identifies three dimensions of Kant's account of autonomy: The autonomous subject has to work out for herself what she ought to do, (Deligiorgi 2012: 4) she should want to do the right thing because it is the right thing to do (ibid.) and she should have the capacity to respond to rational practical principles (ibid.).

${ }^{7}$ This reading has a considerable tradition, Allen Wood being one of its most popular champions.

8 ' $[\mathrm{K}]$ nowledge of the will, thanks to Kant's philosophy, has won its firm foundation and starting-point for the first time through the thought of its infinite autonomy'. (Hegel 2008: 130,131).

${ }^{9}$ See Hegel 2008: 130.

10 'In every philosophy of reflection, like Kant's [...] freedom is nothing else but this formal self-activity.' (Hegel 2008: 38). Klaus Vieweg identifies this emptiness with the indeterminacy in the Philosophy of Right's \5: '[The I] is free insofar as it is able to initiate a chain of events'. (translation by author) (Vieweg 2012: 60).

11 See Hegel 2008: 131.

12 This interpretation rejects Pinkard's "received view's" notion that Hegel generates content from a 'historicized notion of community or with some view of divine destiny or with some amalgam of the two' (Pinkard 1991: 78). Fabian Freyenhagen identifies three different dimensions of this criticism in Freyenhagen 2007: 45-46.

13 E.g. Kant 1998: 39.

14 Kant 1996: 281-282.

15 For a critique of this option see e.g., Pippin 1991: 114 and Lottenbach and Tenenbaum 1995.

16 One strategy of defending Kant against Hegel's interpretation is to argue that the categorical imperative does not produce maxims but rather judges them. (e.g. Pinkard 1991) However, the notion that the categorical imperative ought to judge a maxim implies that the two are separate entities and thereby denies the existence of the kind of logical nexus that is necessary for deducing one from the other.

17 Conceptually, the logical dimension of indeterminacy can be read to represent constructivist concerns with a dynamic notion of normativity. For reasons why Hegel cannot be reduced to the constructivist perspective see Stern 2007 and Hegel 2008: 131.

${ }^{18}$ For an interesting discussion of the role of motivation in Hegel's moral theory, see Yeomans 2013. Hegel's rational agent is motivated by the pursuit of the rational ends of participation in 


\section{Sebastian Stein}

family life, civil society and the state. At the level of appearance, i.e. where individual agents differ from the ends, this should be done in harmony with the agents' specific talents.

19 'From this point of view, no immanent doctrine of duties is possible; [...] if the definition of duty is taken to be the absence of contradiction, formal correspondence with itself - which is nothing but the establishment of abstract indeterminacy - then no transition is possible to the specification of particular duties nor [...] is there any criterion in that principle for deciding whether it is or is not a duty.' (Hegel 2008: 131)

${ }^{20}$ Logically consistent anarchist utopias are a point in case. See also e.g., Pinkard 1991: 71. Also: 'The further Kantian formulation - the possibility of envisaging an action as a universal maxim—does lead to the more concrete representation of a situation, but in itself it contains no principle beyond formal identity and the 'absence of contradiction'. (Hegel 2008: 131)

21 A functioning slave-driven economy is not only logically possible but has been historically manifest (e.g., Sparta before and during the Peloponnesian war).

22 See e.g., Pippin 1991.

23 Kant 1991: 190.

${ }^{24}$ While Hegel acknowledges them as rationally valid ends in their own right, he denies that Kant deduces them from the concept of the consistently behaving subject. See e.g., Lottenbach and Tenenbaum (1995: 228) Also Hegel: '[T]he question arises: what is my duty? As an answer nothing is [...] available except: (a) to do right, and (b) to promote welfare, one's own welfare, and welfare in universal terms, the welfare of others [...] These determinations, however, are not contained in the definition of duty itself' (Hegel 2008: 130).

25 For a recent discussion of the merits and problems of a systematic appropriation of the Philosophy of Right in general and of Thom Brooks' recent interpretation in particular, see Redding 2012, Rosen 2012, Wood 2012 and Brooks 2012.

${ }^{26}$ Hegel 2008: 28. While the Philosophy of Right's 'morality' section discusses a specific form of Hegel's account of rational action, its most general conceptual architecture is located in the work's introduction. The concept of moral action is but a specific determination that rational action as individuality contains.

27 'The will contains $[\ldots]$ the element of pure indeterminacy $[\ldots]$ which involves the dissolution of every restriction and every content [...]. This is the unrestricted infinity of absolute abstraction [...] the pure thought of oneself.' (Hegel 2008: 28). Hegel's use of the term 'universality' as equivalent to indeterminacy might be confusing as it contradicts the most commonly held notion of universality as 'allness', i.e., that some property is shared by all entities within a given set. See e.g., Hegel 2010: 572, 573.

28 'At the same time, the $I$ is also the transition from undifferentiated indeterminacy to the differentiation, determination, and positing of a determinacy as a content and object.' (Hegel 2008: 30). Yeomans equates indeterminacy with internal determination and determinacy with external determination: see Yeomans 2012: 36.

29 'This second moment-determination-is negativity and cancellation [Aufheben] like the first, i.e. it cancels the abstract negativity of the first. [It] follows that this second moment is 


\section{Hegel and Kant on rational willing: The relevance of method}

already contained in the first and is simply an explicit positing of what the first already is in itself [an sich].' (Hegel 2008: 30)

${ }^{30}$ Hegel's proof that these are the two logically necessary building blocks of the notion of rational action is given in the parts of his system (i.e., the Encyclopedia of Philosophical Sciences) that precede the section on practical spirit.

31 'The first moment [of indeterminacy] is [...] only something determinate, one-sided; i.e., being abstraction from all determinacy, it is itself not without determinacy' (Hegel 2008: 30).

32 '[D] etermination - is negativity and cancellation [Aufheben] like [indeterminacy], i.e. it cancels the abstract negativity of [indeterminacy]. Since in general [determinacy] is contained in [indeterminacy], it follows that this second moment is already contained in the first'. (Hegel 2008: 30)

33 Yeomans associates indeterminacy with internality and determinacy with externality and describes this as Hegel's attempt to define freedom as a kind of 'self-determination that arises from his attempt to think externality as a form of internality and vice versa.' (Yeomans 2012: 36)

${ }^{34}$ Hegel uses 'individuality' here in the sense of 'subjectivity' rather than '(one) individual thing' - which he calls 'immediate individuality'. Houlgate describes this in terms of the individual agent: '[A]lthough one has settled on this possibility rather than that, one is not bound by any of them and could always have settled on something else' (Houlgate 1995: 866) - where the something else must be identical with oneself. For a discussion of the different meaning of individuality, see Vieweg 2012: 51.

35 As opposed to the process of dialectical thinking, which suggests a horizontal, mutual dependency of agents and institutions.

36 Robert Stern describes this convincingly in terms of a fit between the moral commands that a subject receives in a rational state's ethical community and the individual itself: ' $[\mathrm{F}]$ or Hegel, [...] social duties are not inimical to the freedom of the individual, in so far as this 'ethical substance' is not 'alien to the subject' - where ' $[\mathrm{o}] \mathrm{n}$ the contrary, the subject bears spiritual witness to them as to its own essence". (Stern 2011: 170) Vieweg describes this as '[T]rue self-determination of the I, which determines itself [...] so that something particular can exist, but which remains identical with itself in doing so, and "connects itself only with itself"” (Vieweg 2012: 66).

37 This means Hegel is neither compatibilist nor incompatibilist with regards to free will since he rejects the debate's implicit assumption that the will is either determined or undetermined. Within individuality, it is both.

38 Hegel 2008: 31.

39 For a discussion of the role of speculative thought in theoretical philosophy see e.g., Sedgwick 2012: 14ff. Yeomans frames this in terms of 'forms of reason' in: Yeomans 2012: 262.

40 These methods of understanding, reflection and speculative thinking are associated to the three parts of the Science of Logic (see e.g., Pinkard 1991: 73ff). 


\section{Sebastian Stein}

41 While the understanding is associated with the passing of one determination into another (e.g., in the logic of being), reflection is supposed to capture the relational qualities that characterise the logic of essence.

42 In the Science of Logic, Hegel describes speculation as the method of the concept - and thus of freedom, individuality and of philosophical thought in general (Hegel 2010: 10). See also Inwood 1992: 271-274.

43 See: 'The resolution of this contradiction is not the acknowledgment of the equal correctness, and of the equal incorrectness, of [infinity and finitude] - this would only be another shape of the still abiding contradiction - but the ideality of both, in the sense that in their distinction, as reciprocal negations, they are only moments. (Hegel 2010: 122).

44 See also Hegel 2010: 35.

45 Hegel describes this relationship in the context of the concept (Hegel 2010: 546). It also articulates itself in the different determinations that define the architecture of the Philosophy of Right. Insofar as these are aspects of individuality for Hegel, they are aspects of freedom. See e.g., Merrill 2012: 26.

46 See e.g., 'In [individuality], the earlier true relation, the inseparability of the determinations [of indeterminacy and determinacy] of the concept, is posited; for as the negation of negation, [individuality] contains the opposition of those determinations and this opposition itself at its ground or the unity where the determinations have come together, each in the other' (Hegel 2010: 548)

47 This unity is individuality, not individuality in its immediacy as a unit, our first idea of individuality, but individuality in accordance with its concept; indeed, individuality in this sense is precisely the concept itself.' (Hegel 2008: 32, emphasis added)

48 See e.g., Hegel 2010: 406.

\section{Bibliography}

Brooks, T. (2007), Hegel's Political Philosophy. Edinburgh: Edinburgh University Press.

Brooks, T. (2012), 'Reply to Redding, Rosen and Wood', Hegel Bulletin 33:2:23-35. Deligiorgi, K. (2012), The Scope of Autonomy. Oxford: Oxford University Press. Freyenhagen, F. (2007), 'The empty formalism objection revisited: $₫ 135 \mathrm{R}$ and recent Kantian responses' in T. Brooks Hegel's Political Philosophy. Edinburgh: Edinburgh University Press, 43-72.

Hill, T. E. Jr. (1992), Dignity and Practical Reason in Kant's Moral Philosophy. Ithaca: Cornell University Press.

Hegel, G. W. F. (1991), Ensylklopädie der philosophischen Wissenschaften im Grundrisse (1830). Hamburg: Felix Meiner Verlag.

Hegel, G. W. F. (1991a), The Encyclopaedia Logic, with the Zusätze: Part I of the Encyclopaedia of philosophical sciences with the Zusätze, trans. T. F. Geraets W. A. Suchting and H. S. Harris. Indianapolis: Hackett. 
Hegel, G. W. F. (2008), Outlines of the Philosophy of Right, Oxford World's Classics, transl. Knox\&Houlgate. Oxford: Oxford University Press.

Hegel, G. W. F. (2010), The Science of Logic, trans. G. Giovanni. Cambridge: Cambridge University Press.

Herman, B. (1993), The Practice of Moral Judgment. Cambridge, MA: Harvard University Press.

Honneth, A. (2010), The Pathologies of Individual Freedom: Hegel's Social Theory. Princeton: Princeton University Press.

Houlgate, S. (1995), 'The Unity of Theoretical and Practical Spirit in Hegel's Concept of Freedom', The Review of Metaphysics 48:4:859-881.

Hoy, D. C. (1989), 'Hegel's Critique of Kantian Morality', History of Philosophy Quarterly 6:2:207-232.

Inwood, M. (1992), A Hegel Dictionary. Oxford: Oxford University Press.

Kant, I. (1991), The Metaphysics of Morals. Cambridge: Cambridge University Press. Kant, I. (1996), The Cambridge Edition of the Works of Immanuel Kant: Practical Philosophy, Ed. and trans. Mary J. Gregor. Cambridge: Cambridge University Press.

Kant, I. (1998), Groundwork of the metaphysics of morals, Ed. and trans. Mary J. Gregor. Cambridge: Cambridge University Press.

Korsgaard, C. (1985), 'Kant's Formula of Universal Law', Pacific Pbilosopbical Quarterly 66.

Larmore, C. (2008), The Autonomy of Morality. Cambridge: Cambridge University Press.

Lottenbach, H. and Tenenbaum, S. (1995), 'Hegel's Critique of Kant in the Philosophy of Right', Kant-Studien 86:211-230.

Merrill, D. C. (2012), 'The Great Financial Crisis: an Ethical Rejoinder', Hegel Bulletin 33:1:19-32.

O’Neill, O. (1975), Acting on Principle. New York: Columbia University Press. Patten, A. (2002), Hegel's Idea of Freedom. Oxford: Oxford University Press.

Pinkard, T. (1991), 'Self-Understanding and Self-Realizing Spirit in Hegelian Ethical Theory', Philosophical Topics 19:2.

Pippin, R. B. (1991), 'Hegel, Ethical Reasons, Kantian Rejoinders', Philosophical Topics 19:99-132.

Pippin, R. B. (2008), Hegel's Practical Philosophy: Rational Agency as Ethical Life. Cambridge: Cambridge University Press.

Rawls, J. (1980), 'Kantian Constructivism in Moral Theory', The Journal of Philosophy 77:515-572.

Rawls, J. (1989), 'Themes in Kant's Moral Philosophy' in E. Förster (ed.), Kant's Transcendental Deductions. Stanford: Stanford University Press.

Redding, P. (2012), 'Thom Brooks's Project of a Systematic Reading of Hegel's Philosophy of Right', Hegel Bulletin 33:2:1-9. 


\section{Sebastian Stein}

Rosen, M. (2007), Freedom in German Idealism. Talk, available online at: http:// scholar.harvard.edu/michaelrosen/publications/freedom-german-idealism. Rosen, M. (2012), 'The ruined castle', Hegel Bulletin 33:2:10-15.

Sedgwick, S. (2012), Hegel's critique of Kant. Oxford: Oxford University Press.

Singer, M. G. (1961), Generalization in Ethics. New York: Knopf publishers.

Stern, R. (2007), 'Freedom, self-legislation and morality in Kant and Hegel: constructivist vs. realist accounts' in E. Hammer (ed.), German Idealism: Contemporary Perspectives. New York: Routledge.

Stern, R. (2011), Understanding Moral Obligation. Cambridge: Cambridge University Press.

Vieweg, K. (2012), Das Denken der Freibeit. Munich: Wilhelm Fink Verlag. Wildt, A. (1982), Autonomie und Anerkennung. Stuttgart: Klett-Cotta Verlag. Winfield, R. D. (2012), 'The Challenge of Political Right', Hegel Bulletin 33:57-70. Wood, A. W. (1999), Hegel's Ethical Thought. Cambridge: Cambridge University Press.

Wood, A. W. (2012), 'Thom Brooks and the 'Systematic' Reading of Hegel', Hegel Bulletin 33:2:16-22.

Yeomans, C. (2012), Freedom and Reflection: Hegel and the Logic of Agency. Oxford: Oxford University Press.

Yeomans, C. (2013), 'Talents and Interests: A Hegelian Moral Psychology', Hegel Bulletin 34:1:33-58. 